always insisted that agricultural education, widely admitted as necessary at least for countrymen, must be based on sound seientific research.

It will not easily be forgotten at Rothamsted how he helped the appeal for funds that had to be made in 1934 when the Lawes family, owners of the estate which included the experimental fields and the laboratories, found they could retain it no longer but must part with it. The fields were then, in the language of the time, 'ripe for development', and builders were already assessing the possibilities for villa residences; no Treasury grants were available for the purchase; the money had all to be raised privately and quickly, and times were hard. Sir Richard gave the appeal whole-hearted support: he and $\mathrm{H}$. G. Wells jointly wrote a letter to The Times in which with his accustomed lucidity he expressed his views on agricultural science: "whatever may be said of other branches of science", he wrote, "the results of research in agriculture cannot be used for purposes of destruction but only to give mankind knowledge by which the factors that determine the production of food may be effectively guided and controlled for the comfort of all. No higher motive of research than this can be conceived".

This was no mere passing expression of opinion: it was his consistent attitude to the subject and it inspired his friendly attitude to the workers. Critics had sometimes asserted that they should devote themselves mainly to the solution of specific farm problems; he always supported the Rothamsted view that their proper function was to build up a systematic science which should relate the facts and seek the underlying causes; it would then be possible to make better use of the facts than when they were only imperfectly known and understood. He had the personal link with Rothamsted that his only son Edgar, after retiring early from the Indian Army, joined the staff as guide demonstrator and thus became one of the pioneers in the art of presenting agricultural science to two completely different audiences: the countryman who already knows many of the facts, and the townsman who is often completely ignorant of them but who depends for his daily bread on their proper understanding by the right people. I always hoped that father and son might collaborate in producing a simple book setting forth the material in easily understandable language, but Edgar's untimely death and Sir Richard's many other activities prevented this. But his services to agricultural science, though quiet and unobtrusive, remain in the memories of those who knew him.

E. JohN RUSSELI

Sir Richard GRegory was president or chairman of many societies and congresses, including the Royal Meteorological Society, the Geographical Association, and also the British Science Guild until that was merged, at his instance, with the British Association in 1936. His kindly spirit set store by the social contacts of conferences only less strongly than did his eagerness to further the progress of science. It is therefore probably true to say that his first and last love among the societies to which he belonged was for the British Association. Of this he became an annual member in 1896 and a life member in 1901. There was no more regular attendant at its annual meetings than he, and the last of these at which he was seen was that at Edinburgh in 1951. This his poor health compelled him to leave before its finish, and at the recent meeting in Belfast his telegram of greeting to the Council was welcomed with inevitable regret.

Gregory's early activities in the Association were concerned with the establishment of the Section of Educational Science in 1901, and with work on various committees appointed at the instigation of that Section. He acted in due course as a secretary and as recorder of the Section. But his first recorded contribution of a paper was not to the educational but to the Section of Geography in 1908, when he presented geography as "one of the most valuable subjects in a school curriculum", as providing not only intellectual discipline but also the human interest of "the most inspiring literature". This theme recurred incidentally in his finely phrased presidential address to the Education Section in 1922.

His presidency of the Association came in 1940 , and was unique in having lasted for six years. During the War there were no annual meetings of the Association on the usual scale, but Gregory eagerly supported the conferences arranged in London by the Association's Division for the Social and International Relations of Science, of which at least one, that on "Science and World Order", which brought together not only British speakers but also foreigners of eminence who had found refuge in Britain, attracted attention far outside the meeting-hall, and indeed beyond the confincs of science itself. Gregory's presidential address, too, was given in unique circumstances, the sole public pronouncement at a one-day meeting in 1946 held in the hall of the British Medical Association, since there had not been time to arrange an annual meeting on the full scale immediately after the end of the War. Whatever disappointment Gregory felt at not presiding over such a meeting was concealed in his readiness to serve the Association to the best advantage as judged by those who worked with him, by one of whom this tribute to his memory is gratefully contributed. O. J. R. Howarth

\section{Memorial Service}

A memorial service for Sir Richard Gregory will be held in St. Martin-in-the-Fields Church, London, on Friday, October 3 , at 12 noon.

\section{NEWS and VIEWS}

\section{Henri Moissan (1852-1907)}

BorN in Paris a century ago, on September 28, 1852, Henri Moissan was appointed demonstrator at the Ecole de Pharmacie, Paris, at the age of twentyseven. After obtaining his doctorate in science in 1885, he became professor of toxicology in the following year, and professor of mineral chemistry in 1889. In 1900 he was called to the chair of chemistry at the Sorbonne. He is best known for having isolated and liquefied fluorine, for which he received the La Caze Prize of the Paris Academy of Sciences in 1887, and for his development of the electric furnace, which made possible the reduction of very refractory metals. His preparation in 1893 of minute artificial diamonds by extremely rapid cooling of a solution of carbon in molten iron created a great sensation at the time. He also simplified the production of acetylene. Moissan shared the Hofmann Medal of the German Chemical Society with Sir William Ramsay in 1903 and was awarded the Nobel Prize for Chemistry in 1906. His most important 